\title{
Trypanosoma cruzi Peptidases: An Overview
}

\author{
Alane Beatriz Vermelho*, ${ }^{*}$, Ana Cristina Nogueira de Melo ${ }^{1}$, Rosangela Araújo Soares ${ }^{1}$, \\ Daniela Sales Alviano ${ }^{1}$, Edilma Paraguai Souza ${ }^{1}$, Thaïs Souto-Padrón ${ }^{1}$, Giseli Capaci Rodrigues ${ }^{2}$, \\ Alcino Palermo de Aguiar ${ }^{2}$, Mirian Claudia Pereira ${ }^{3}$, Antonio Ferreira-Pereira ${ }^{1}$, \\ Maria Socorro S. Rosa ${ }^{1}$, Maria Nazareth Leal Meirelles ${ }^{3}$ and Celuta Sales Alviano ${ }^{1}$
}

\author{
${ }^{I}$ Departamento de Microbiologia Geral, Instituto de Microbiologia Prof Paulo de Góes (IMPPG), Centro de Ciências \\ da Saúde (CCS), Bloco I, Universidade Federal do Rio de Janeiro (UFRJ), Ilha do Fundão, 21941-590, Rio de Janeiro, \\ RJ, Brazil \\ ${ }^{2}$ Instituto Militar de Engenharia (IME), Praça General Tibúrcio 80, Praia Vermelha, CEP 22290-270 RJ, Brazil \\ ${ }^{3}$ Laboratório de Ultraestrutura Celular, Departamento de Ultraestrutura e Biologia Celular, Instituto Oswaldo Cruz, \\ FIOCRUZ, Avenida Brasil 4365, 21045-900, Rio de Janeiro, RJ, Brazil
}

\begin{abstract}
Peptidases are a group of enzymes which have a catalytic function that is to hydrolyze peptide bonds of proteins. The enzymes that hydrolyze peptide bonds at the amino- or carboxy-terminus are classified as exopeptidases, and those that cleave peptide bonds inside the polypeptide are endopeptidases. Endopeptidases, such as cysteine-, metalo-, serine- and threonine peptidases as well as some exopeptidases, have been characterized in Trypanosoma cruzi. Understanding the pathogenesis of $T$. cruzi requires the identification of functional properties of those peptidases, as they are implied in virulence, are important for host-parasite interactions and are critical for successful survival in their hosts. Here we examine the main $T$. cruzi peptidases, focusing on their biological roles, especially concerning the parasite-mammalian host relations.
\end{abstract}

Keywords: Peptidases, Trypanosoma cruzi.

\section{INTRODUCTION}

Trypanosoma cruzi, the causative agent of Chagas disease, also known as American trypanosomiasis, preferentially infects the heart leading to cardiac arrest, which is frequently followed by death [1]. Chagas disease is among the thirteen parasitic tropical infections that are considered to have the highest-burden of the neglected tropical diseases, which together affect more than one billion people worldwide $[2,3]$. They are largely ignored by medical science, first-world public opinion and pharmaceutical companies [4, 5]. T. cruzi, a flagellated protozoan parasite, has a complex life cycle, including two replicative forms: the epimastigote, present in the gut of the insect vector, and the amastigote, an intracellular form in the infected mammal. The two infective non-replicative forms are the metacyclic trypomastigote in the insect vector and the bloodstream trypomastigote released from infected cells into the blood of the mammal. The intracellular lifestyle of $T$. cruzi enables the parasite to evade host defenses and results in the chronic disease stage. Eventually, after years of asymptomatic infection, $15-30 \%$ of patients develop signs of organ damage, which produces characteristic cardiac, digestive or nervous forms of chronic Chagas disease; death is a frequent outcome [6].

\footnotetext{
*Address correspondence to this author at the Departamento de Microbiologia Geral, Instituto de Microbiologia Prof. Paulo de Góes, Universidade Federal do Rio de Janeiro-UFRJ /CCS, Bloco I, Cidade Universitária, Ilha do Fundão, Rio de Janeiro, R.J, CEP: 21941-590, Brazil; Tel: (021) 25626743; Fax: (021) 25608344; E-mail:abvermelho@ @icro.ufrj.br
}

The World Health Organization has estimated that some 16-18 million people are infected throughout the American continent, including 100,000 in the United States, and 120 million people are at risk of infection throughout Central and South America [7]. Two clinical forms are characteristic of this disease, acute and chronic. In the acute phase, a local inflammatory lesion appears at the site where metacyclic trypomastigotes enter, and the parasite spreads throughout the host organism. The presence of myocarditis and/or pathological disturbances in the peripheral nervous system and gastrointestinal system are features observed in the chronic phase. Thirty to forty percent of chronically infected individuals develop cardiac abnormalities and as many as $10 \%$ develop digestive tract diseases [8]. To date, no vaccines have been developed, and there are no prophylactic drugs to prevent infection by $T$. cruzi. Moreover, current available medication, such as nitrofurans (nifurtimox) and nitroimidazoles (benznidazole), are effective during the acute phase of the infection but have little effect in the chronic stage of the disease [9]. In addition, both drugs have serious side effects and resistance against both compounds leads to increasing treatment failures [10]. Taking into account that benznidazole and nifurtimox are considered far from ideal as trypanocidal drugs, the search for new compounds with antiT. cruzi activity, low toxicity and increased efficacy during the chronic phase continues. In the last few years, progress towards new drugs for the treatment of Chagas disease has been disappointing. Chemotherapy still relies on drugs developed decades ago showing limited efficiency and toxic side effects $[11,10]$. Efforts to tackle this disease require 
research on host-parasite interactions, especially the initial events, which may lead to the establishment of the disease and determining when many different parasite molecules are known to be involved [12, 13]. Some headway has been made in identifying targets that are key to parasite virulence and the pathogenesis of the disease. Among the most promising targets for antiparasitic agents are parasite peptidases in order to establish novel, effective and selective chemotherapies. These enzymes play central roles in diverse processes, such as adhesion and cell invasion, quite apart from their obvious participation in the nutrition of the parasite at the expense of the host [14].

Taking into consideration the importance of T. cruzi peptidases in the development of Chagas disease and the fact that they have been described and characterized as promising drug targets [15], this review will primarily focus on our current knowledge of the role of peptidases in virulence, pathogenicity and the development of peptidase inhibitors as potential drugs to treat Chagas disease.

\section{PEPTIDASES}

Peptidases, proteases or proteolytic enzymes are hydrolytic enzymes that cleave peptide bonds in proteins. The MEROPS database is an information resource for peptidases and includes their classification, structure and properties [1618]. Endopeptidases, such as cysteine-, metallo-, serine- and threonine-peptidases as well some exopeptidases, have been characterized in $T$. cruzi. The recent completion of the genome sequence of $T$. cruzi (CL Brener clone) suggests the presence of 70 putative cysteine peptidases, about 40 putative serine peptidases, 250 putative metallo-peptidases (of which most are homologues to leishmanolysin (Gp63), 25 putative threonine peptidases (most of which are homologues of proteasome Subunits), and 2 putative aspartyl peptidases. It is noteworthy that among the latter, the complete absence of A1 family peptidases (pepsin-like) has been reported for the genomes of the three trypanosomatids analyzed: T. cruzi, Leishmania major and Trypanosoma brucei [19]. The genes detected in $T$. cruzi were putative presenilin-

Table 1. Major Trypanosoma cruzi Peptidases

\begin{tabular}{|c|c|c|c|c|c|c|}
\hline Catalytic type & Peptidase Name & Endo-Exopeptidase & Clan & Family & NC-IUBMB & MEROPS ID \\
\hline \multirow{4}{*}{ Cysteine } & Cruzipain (CZP) & Endo & $\mathrm{CA}$ & $\mathrm{C} 1$ & 3.4.22.51 & $\mathrm{C} 01.075$ \\
\hline & $\begin{array}{l}\text { Cathepsin B-like cys- } \\
\text { teine endopeptidase }\end{array}$ & Endo & $\mathrm{CA}$ & $\mathrm{C} 1$ & $*$ & C01.098 \\
\hline & Metacaspase 9 & Endo & $\mathrm{CD}$ & $\mathrm{C} 14$ & $*$ & $\mathrm{C} 14.034$ \\
\hline & Calpain & Endo & $\mathrm{CA}$ & $\mathrm{C} 2$ & $*$ & $\mathrm{C} 02.024$ \\
\hline Serine & $\begin{array}{c}\text { Oligopeptidase B (Tc } \\
80)\end{array}$ & Endo & $\mathrm{SC}$ & S9 & 3.4 .21 .83 & S09.010 \\
\hline \multirow{2}{*}{ Metallo } & $\begin{array}{l}\text { Metallopeptidases } \\
\text { (carboxypeptidase) }\end{array}$ & Exo & MA & M32 & $*$ & M32.004 \\
\hline & GP63 & Endo & MA & M8 & 3.4 .24 .36 & M08.001 \\
\hline Threonine & Proteasome & Endo & $\mathrm{PB}$ & $\mathrm{T} 1$ & 3.4 .25 .1 & $\begin{array}{c}\text { (subunit 1) T01.010 } \\
\text { (subunit 2) T01.011 } \\
\text { subunit } 3 \text { T01.012 } \\
\text { (subunit alpha 2) } \\
\text { T01.972 } \\
\text { (subunit alpha 7) } \\
\text { T01.974 } \\
\text { (subunit alpha 5) } \\
\text { T01.975 } \\
\text { (subunit alpha 1) } \\
\text { T01.976 }\end{array}$ \\
\hline
\end{tabular}

*Not yet included in IUBMB. 
like aspartic peptidase, Clan $\mathrm{AD}$, family $\mathrm{A} 22 \mathrm{~A}$ and putative signal peptide peptidase, aspartic peptidase, Clan $\mathrm{AD}$, family A22B [20, 21]. However, recently two aspartyl peptidases were identified in T. cruzi by Pinho [22]. In the aspartyl peptidases section, this question will be briefly discussed.

Several functions had been described for peptidases in $T$. cruzi, including virulence factors. Besides this, they are important enzymes for host-parasite interactions, and they are critical for successful parasite survival [23]. Table 1 summarizes the major $T$. cruzi peptidases.

\section{CYSTEINE PEPTIDASES}

Cysteine peptidases present a catalytic cysteine residue, which mediates protein hydrolysis via a nucleophilic attack on the carbonyl carbon of a susceptible peptide bond [2426]. A closely related family of cysteine peptidases, known as cruzipain (CZP), cruzain (the recombinant catalytic domain of cruzipain), or GP57/51, constitutes the major cysteine peptidase activity in $T$. cruzi $[9,27,28]$. Another cysteine found in this parasite is a $30-\mathrm{kDa}$ cathepsin B-like cysteine peptidase [29]. The occurrence of Metacaspases [21], and recently the Calpains, have also been described in this parasite [30,31].

\section{Cruzipain}

Cruzipain is encoded by a family of genes organized as a series of tandem repeats located on different chromosomes. It is expressed as a complex mixture of isoforms in the main developmental stages throughout the $T$. cruzi life-cycle, i.e., in the extracellular trypomastigote, amastigote and insect epimastigote stages. Activity levels are highest in epimastigotes, and depending on the life cycle stage, cruzipain is found on the cell surface of $T$. cruzi amastigotes or lysosome-like organelles present on $T$. cruzi epimastigotes called reservosomes [32-34].

Like the mammalian enzyme, the trypanosome peptidases are synthesized as pre-pro-proteins [14, 35]. This enzyme, with a molecular mass ranging from 40 to $60 \mathrm{kDa}$, is an endopeptidase able to digest several protein substrates including casein, bovine serum albumin, denatured hemoglobin and also small peptides [24]. Duschak and collaborators [36] reported a novel cysteine secreted by metacyclic trypomastigotes, named TcCPmet, migrating in SDS-gelatin at 98-116 $\mathrm{kDa}$. This novel proteolytic activity did not react with anti-cruzipain antibodies, suggesting that this extracellular enzyme is not a cruzipain homologue.

In addition to their role in parasite nutrition as its major lysosomal peptidase, the cysteine peptidases have been implicated in a number of cellular processes including cell invasion, proliferation, parasite differentiation and metacyclogenesis. Recent studies demonstrated that tissue culture trypomastigotes generate kinins through mechanisms that involve cooperative interactions between cruzipain, high molecular weight kininogens (HK) and heparan sulfate proteoglycans $[1,37]$, as described in the section "Role of peptidases in T. cruzi interaction" of this review. It is also an immunodominant antigen recognized during human infection, with a possible participation in the defense of the parasite against the immune system of the mammalian host $[1,38]$.

\section{Cathepsin B-Like Cysteine Endopeptidase}

In addition to cruzipain, which shows homology with cathepsin L peptidase, T. cruzi life-cycle forms express cathepsin $\mathrm{B}$, a peptidase considered a virulence factor, as evidenced by its overexpression in a parasite stock resistant to cruzipain inhibitor. The enzyme has been purified and shown to be an acidic cysteine peptidase of $30 \mathrm{kDa}$ with broad substrate specificity $[29,39,40]$. Sera from both chagasic rabbits and humans have specific antibodies to highly purified native oligopeptidase B and cathepsin B. The antibody levels to cathepsin $\mathrm{B}$ were higher than those observed to oligopeptidase B. Sera from mucocutaneous leishmaniasis and kala-azar patients have antibodies that recognize cathepsin B as an antigen, showing cross reactivity. Despite high levels of specific antibodies, sera from $T$. cruzi-infected patients did not inhibit cathepsin B activity. One possible function for both oligopeptidase B and cathepsin B, associated with Chagas disease pathogenesis would be to hydrolyze host proteins and induce host immune responses after enzyme release upon parasite lysis [41].

\section{Metacaspases}

The caspases are a family of cysteine peptidases that are the main effectors of apoptosis or programmed cell death [42]. Until recently, it was thought that lower eukaryotes might lack caspases because no homologous caspase genes had been discovered in the yeast genome or in the genome of any parasitic protozoa. Recently, the genome of $T$. cruzi CL Brener was shown to contain two genes, TcMCA3 and TcMCA5, with homology to those encoding metacaspases. TcMCA3 is expressed in the four major developmental stages of the parasite, whereas TcMCA5 is expressed only in the epimastigote form [20]. Experimental evidences suggest that the metacaspases might be involved in programmed cell death (PCD) of the parasite [21]. Caspase-like protein activity was also detected in epimastigotes of $T$. cruzi maintained in axenic cultures [43].

Caspase-like activity was detected in parasites at exponential and stationary phases of growth using acetyl-AspGlu-Val-Asp p-nitroanilide (Ac-DEVD-pNA), a caspase-3 specific substrate. At the stationary phase of growth, caspase 3-like activity increases, suggesting that this type of cysteine-protease could be involved in apoptosis-like cell death observed in the parasites. The presence of caspase 3-like proteins was confirmed by Western Blot using polyclonal heterologous antibodies against human procaspase 3 , both in T. cruzi Tulahuen and MF strains [43], presenting the expected molecular mass for $T$. cruzi metacaspase 3 found by Kosec [21].

\section{Calpains}

Calpains are calcium-dependent cysteine peptidases involved in several physiological functions including apoptosis, signal transduction, cell differentiation and cytoskeleton remodeling $[44,30]$. In humans, they exist in two major isoforms, m-calpain and $\mu$-calpain, which require millimolar and micromolar concentrations of $\mathrm{Ca}^{2+}$, respectively, for their activation [31]. The gene encoding the T. cruzi CALP, TcCALPx11 (GeneDB ID Tc00.1047053506563.210), was identified by microarray analysis as being differentially expressed in $T$. cruzi during metacyclogenesis. Recently, a cal- 
pain inhibitor III (MDL28170) was used to detect calpainlike molecules in epimastigote forms of the $T$. cruzi isolate Dm28c. A $80 \mathrm{kDa}$ reactive protein was detected by Western blotting [30]. Different levels of CALPs expression were also detected in distinct phylogenetic lineages, such as $\mathrm{Y}$ strain (lineage TCI), Dm28c (TCII) and INPA6147strain (Z3 zymodeme). Addition of $70 \mathrm{mM}$ of MDL 28170 to the culture medium promoted a strong reduction in the growth rate of epimastigote forms of the parasite suggesting an in vivo relevance. [31].

\section{SERINE PEPTIDASES}

The prolyl oligopeptidase family cannot hydrolyze peptides containing more than about 30 residues. This group is unrelated to the classical trypsin and subtilisin families and includes dipeptidyl peptidase IV, acylaminoacyl peptidase and oligopeptidase $\mathrm{B}$, in addition to the prototype prolyl oligopeptidase. In trypanosomatids, serine peptidase research has centered on the Clan SC peptidases, oligopeptidase B (OpdB) and prolyl oligopeptidase (POP) [45]. T. cruzi-host cell invasion studies have shown that oligopeptidase $\mathrm{B}$ generates an active $\mathrm{Ca}^{2+}$-agonist from a cytosolic precursor molecule. Deletion of OpdB impairs the ability of T. cruzi to invade host cells and attenuates virulence in vivo [12, 46, 47]. Antibodies to the recombinant oligopeptidase B inhibited both peptidase activity and $\mathrm{Ca}^{2+}$-signaling [46]. T. cruzi prolyl oligopeptidases (POP) specifically hydrolyze human collagen (Types I and IV) and fibronectin and have been implicated in the parasite adhesion to host cells and cell entry $[48,49]$. Relatively less work has been focused on chemotherapeutic hits or leads against protozoan serine peptidases, but interest in protozoan subtilisin-like targets is increasing. The invasive capacity of $T$. cruzi is reduced in vitro in the presence of OpdB and POP inhibitors $[45,48,50]$.

$T$. cruzi also has shown serine carboxypeptidase activity belonging to the $\mathrm{C}$ group of serine carboxypeptidases, within the S10 serine peptidase family, which shows a high similarity to plant and yeast enzymes [51]. The enzyme is a monomeric glycoprotein with a molecular mass of $54 \mathrm{kDa}$, and is highly specific for hydrophobic C-terminal amino acid residues, and is strongly inhibited by 3,4-dichloroisocoumarin. Recently, it was demonstrated that this proteolytic activity is present in lysosome-related organelles as cruzipain [34].

\section{METALLOPEPTIDASES}

In recent years, the number of identified metallopeptidases has increased dramatically. In the Trypanosomatidae family, these enzymes play important roles in nutrition, pathogenicity, survival and interaction with the host [24]. Metallopeptidase activities have been described in several monogenetic and digenetic trypanosomatids [52-54], but only the so-called gp63 from Leishmania spp. has been thoroughly characterized. Genes homologous to gp63 of Leishmania are also present in this parasite. Four gp63 homologous genes in $T$. cruzi are differentially expressed, being more abundant in amastigotes than in epimastigotes or trypomastigotes [55].

In $T$. cruzi, different metallopeptidase activities have been previously described, some of them expressed specifically during metacyclogenesis in various strains and clones of $T$. cruzi $[56,57]$. In addition, Cuevas [58] described that
T. cruzi possesses a family of gp63 genes composed of multiple groups. Two of the groups, Tcgp63-I and Tcgp63-II, are present as high-copy-number genes and antibodies against Tcgp63-I partially blocked the infection of Vero cells by trypomastigotes, which suggests a possible role for this metallopeptidase during the infection process in vitro.

Matrix metallopeptidases (MMPs) are a family of structurally related zinc-dependent peptidases that are thought to be responsible for normal matrix remodeling and pathological tissue destruction by virtue of their ability to hydrolyze the major components of the extracellular matrix (ECM) [59].

Earlier studies from our laboratory showed that MMP-9like activity was detected in the cytoplasm of $T$. cruzi during in vitro infection of embryonic hepatocyte cells [60]. Peptidase-dependent extracellular matrix remodeling is one of the events that it is emerging as a key regulator of $T$. cruzi infection and the pathogenesis of Chagas disease. So, the presence of MMP-9-like activity in T. cruzi may contribute to ECM protein degradation facilitating invasion of host cells, an activity that is likely to be highly relevant in vivo during the navigation of interstitial tissue spaces by trypomastigote forms [61]. Recently, it has been shown that the expression and activity of two MMPs, MMP-2 and MMP-9, are upregulated in cardiac tissue during the acute phase of $T$. cruzi infection and they are detected in association with inflammatory cells infiltrating the myocardium [62]. Additionally, in order to establish the role of MMPs in vivo, $T$. cruzi-infected mice were treated with doxycycline, a potent inhibitor of MMP activity. It was found that mice treated with doxycycline showed significantly decreased heart inflammation, delayed peak of parasitemia and improved survival rates, compared with the control group. This evidence suggests an important role for MMPs in the induction of $T$. cruzi-induced acute myocarditis. Furthermore, our group has demonstrated for the first time MMP-9-like activity in T. cruzi [63]. Gutierrez et al [62] showed that MMP-9 expression is upregulated during $T$. cruzi infection.

The study of exopeptidases in $T$. cruzi, on the other hand, has received little attention. Two metallocarboxypeptidases (MCPs) of the M32 family from $T$. cruzi CL Brener clone have recently been characterized: $T c \mathrm{MCP}-1$ and $T c \mathrm{MCP}-2$ [64]. The structure of TcMCP-1 shows strong topological similarity with archaeal, bacterial and mammalian metallopeptidases including angiotensin-converting enzyme, neurolysin and thimet oligopeptidase [65].

Thus, TcMCPs might be involved in the degradation of peptides, such as those produced by the proteasomes, in the cytosol. However, a possible role in the processing of proteins and small regulatory peptides cannot be excluded. These are the first members of this family to be characterized in a eukaryotic organism, and these peptidases may be a new target for the development of a rational chemotherapy against Chagas disease and other diseases caused by trypanosomatids.

\section{PROTEASOME}

In eukaryotic cells, the turnover of intracellular proteins is mediated mainly by the machinery of the ubiquitin/adenosine-5' -triphosphate (ATP)-dependent protea- 
some pathway, which is a strictly controlled enzymatic complex $[66,67]$. The mechanism of degradation is successive: protein substrates selected for destruction are tagged by the covalent addition of poly-ubiquitin chains (E1-E3 ubiquitin conjugation pathway), which are recognized and proteolytically degraded by the multifunctional $26 \mathrm{~S}$ proteasome complex, a large non-lysosomal multi-subunit and multi-catalytic peptidase complex located in the cytosolic and the nuclear compartments [68]. This proteolytic pathway controls a broad array of cellular functions, including stage-specific gene transcription [69], antigen-processing [70], cell cycle progression [71], regulation of membrane-anchored and secretory pathway-compartmentalized proteins [72] and protein quality control [73].

The functional proteasome (known as $26 \mathrm{~S}$ proteasome) is an ATP-dependent, multifunctional proteolytic complex that differs in many respects from typical proteolytic enzymes [74]. It consists of a proteolytic core particle, the 20S (720 $\mathrm{kDa}$ ) proteasome, capped at one or both ends by a regulatory component termed the $19 / 22 \mathrm{~S}$ complex $(890 \mathrm{kDa})$ (regulatory particle), also called the proteasome activator (PA)700, composed of at least 18 peptides that determine substrates specificity for the selective degradation of ubiquitinated proteins [75]. Ubiquitinated substrates are processed at the active sites located within the inner cavity of the core particle, whereas the regulatory particle is responsible for recognition, unfolding and translocation of the selected substrates into the lumen of the core particle.

Mammalian cells and the protozoan T. brucei also contain an ATP-independent activator of the 20S proteasome, named the PA28 or PA26 complex, respectively, that can replace 19S and activates the proteolysis of short peptides. The PA28 activator is a $200 \mathrm{kDa}$ ring-shaped heteromultimer composed of two isoforms of a $28 \mathrm{kDa}$ subunit (PA28 $\alpha$ and PA28 $\beta$ ) and is present in the cytoplasm as a free complex or associated with the proteasome. Crystallographic studies of the 20S proteasome revealed a complex cylindrical structure made up of four stacked heptameric rings composed of seven different $\alpha$-subunits in the outer rings and seven different $\beta$ subunits in the inner ones. The active sites reside within the $\beta$-subunits, which provide the catalytic N-terminal threonine residues. The eukaryotic $20 \mathrm{~S}$ proteasome shows several distinct proteolytic activities, since in vivo assays with chromogenic substrates demonstrated the following activities: a chymotrypsin-like activity, a trypsin-like activity, a peptidylglutamyl-peptide-hydrolyzing activity, a branched chain amino acid-preferring activity and a small neutral amino acid-preferring activity. However, the chymotrypsin-like activity and the trypsin-like activity are considered the main activities [76].

The presence of the $26 \mathrm{~S}$ proteasome and the ubiquitin pathway in $T$. cruzi was documented for the first time by De Diego [77]. The $26 \mathrm{~S}$ proteasome of $T$. cruzi epimastigotes was identified as a high molecular mass complex (1400 kDa) with a composition that resembles that of the $26 \mathrm{~S}$ proteasome isolated from other eukaryotic cells and with an ATPdependent chymotrypsin-like activity against the substrate Suc-Leu-Leu-Val-Tyr-AMC (Suc corresponding to Succinyl, AMC being 7-amino-4-methylcoumarin). Some members of the highly conserved AAA family of ATPases present in the
$19 \mathrm{~S}$ complexes that cap the $26 \mathrm{~S}$ proteasomes were also identified [78]. The characterization of the proteasomes from trypanosomes and their comparison with rat proteasomes has shown that they share structural similarities but are functionally distinct [79]. Therefore, it would be of great interest to investigate the subunit composition of trypanosome proteasomes further and to compare it with that of proteasomes from other organisms, as well as to isolate genes encoding proteasomal subunits. Two genes encoding T. cruzi proteasome subunits $\alpha_{1}$ [80] and $\alpha_{6}$ [81] were cloned and characterized and the results showed that the $T$. cruzi proteasome might be composed of the same set of subunits as other eukaryotes. However, it is still not clear whether all of the corresponding $\alpha$ - and $\beta$ - family subunits are found in the proteasomes of early diverging eukaryotes, such as $T$. cruzi.

Experiments with specific inhibitors of proteasome activity such as peptide aldehydes (e.g. N-carbobenzoxyl-LeuLeu-leucinal, MG132), lactacystin and gliotoxin have helped to define the role of the proteasome in various parasitic protozoa processes, including replication and differentiation [82]. Proteasome involvement in the stage-specific trypomastigote-amastigote transformation has been a special focus of attention in $T$. cruzi. Since this parasite undergoes shape changes, genes must be turned on and off and the proteins must be selectively degraded and synthesized [83].

T. cruzi treatment with lactacystin inhibits both the transformation of trypomastigotes into amastigotes and the development of amastigotes into trypomastigotes, thus implicating proteasomes in parasite remodeling [84]. Moreover, lactacystin treatment promotes the conjugation of ubiquitin to flagellar proteins and the accumulation of ubiquitinated products during transformation [77, 84]. It seems that proteasome activity is not required for host cell invasion since lactacystin pre-treatment of trypomastigotes $(10 \mu \mathrm{M})$ caused no effect on the number of intracellular parasites in cultured myoblasts [82]. Recently, Cardoso [85] found that epimastigotes treated with lactacystin were still able to adhere to the culture flask walls, but did not differentiate into metacyclic trypomastigotes. In addition, lactacystin treatment blocked epimastigote multiplication, since flow cytometry data demonstrated that $T$. cruzi epimastigotes cultured in lactacystincontaining LIT medium were arrested at the G2 phase of the cell cycle. These findings suggest that proteasomes are involved in $T$. cruzi cell growth and metacyclogenesis in vitro.

Antigenic peptides derived from intracellular proteins are continuously presented to the immune system by MHC class I molecules on the surface of immune and non-immune cells, and the major proteolytic system generating peptide ligands are dependent on proteasomes. The $20 \mathrm{~S}$ proteasome is the key peptidase generating peptides for the MHC class I antigen presentation pathway. In this context, studies have been done in order to answer whether in vitro $T$. cruzi infection might influence the gene expression or protein profile of the $20 \mathrm{~S}$ proteasome [86].

\section{ASPARTIC PEPTIDASES}

Aspartic peptidases are a relatively small group of proteins that have received enormous interest because of their significant roles in human diseases. In $T$. cruzi (epimastigote forms), two aspartic peptidases have been isolated and iden- 
tified as cruzipsin-I (CZP-I) and cruzipsin-II (CZP-II). Both peptidases show a molecular mass of $120 \mathrm{kDa}$ by HPLC gel filtration. By the substrate-sodium dodecyl sulphatepolyacrylamide-gelatin gel electrophoresis method, it was possible to detect the activity of the enzymes in a doublet of bands at 56 and $48 \mathrm{kDa}[87,89]$. Nevertheless, due to large difficulty to correlate homologous genes by computer techniques of both peptidases, there are still several sequences that have not been correctly identified [19, 20, 21]. Moreover, the physiological role of these T. cruzi peptidases has not been completely understood [87].

\section{ROLE OF PEPTIDASES IN TRYPANOSOMA CRUZI- HOST CELL}

\section{Interaction}

Peptidases play a key role in the life cycle of protozoan parasites and are relevant for several aspects of host-parasite interactions $[14,15,88]$. T. cruzi peptidases have been implicated in the early events of parasite invasion process, intracellular development and parasite egress [89-91]. Many signaling pathways have been described to promote parasite entry [92-94]. One of these pathways of $T$. cruzi invasion in mammalian cells involves the enzyme Oligopeptidase B $(\mathrm{OpbB})[92,95,96]$. The activity of OpbB induces the release of $\mathrm{Ca}^{2+}$ agonist from the parasite that binds to a host cell receptor and activates phospholipase C, leading to IP3mediated $\mathrm{Ca}^{2+}$ release from host cell intracellular stores [97, 98]. The transient increase of cytoplasmic $\mathrm{Ca}^{2+}$ levels incites host cell F-actin disassembly at the parasite adhesion site and triggers lysosomal exocytosis, regulated by synaptotagmin VII [99], allowing the formation of the parasitophorous vacuole containing lysosomal markers.

Cruzipain, the major cysteine peptidase in $T$. cruzi, is an alternative mechanism of trypomastigote invasion that also induces $\mathrm{Ca}^{2+}$ mobilization and recruitment of lysosomes $[23,90,100]$. The kinin-mediated pathway is modulated by heparan sulfate glycosaminoglycans, which potently enhances kinin release by $T$. cruzi [38]. Kinin peptide signal is triggered by the $\mathrm{B} 2$ type of bradykinin receptor (B2R) in human primary umbilical vein endothelial cells (HUVECs) or Chinese hamster ovary (CHO) cells overexpressing B2R (CHO-B2R) [101]. However, T. cruzi invasion is also engaged by B1R with requirement of kininase I [101]. B1R or B2R antagonists and DL-2-mercaptomethyl-3-guanidinoethylthiopropanoic acid (MGTA) and E-64 inhibitors impair parasite entry $[100,101]$. Studies underlying the mechanism of cruzipain proteolytic function have demonstrated that chagasin, member of a family of tight-binding cysteine protease inhibitors, has the ability to bind cruzipain, through its loop domains L2, L4 and L6 and regulate its activity [102, 103]. Besides the involvement of cruzipain on $T$. cruzi invasion [90] and intracellular development [104], this peptidase also plays an important role in parasite egress. Inhibition of cruzipain by the peptidase inhibitor Phe-Ala-FMK reduced $T$. cruzi egress in dose dependent way, achieving a maximal inhibition at $100 \mu \mathrm{M}$ of inhibitor [89]. In addition, T. cruzi presents a homologue of Leishmania Gp63, which is GPIanchored and presents metallopeptidase activity. Blockage of trypomastigote invasion by anti-TcGp63-I antibodies suggests the involvement of this molecule in T. cruzi entry [58].
However, the mechanism involved in this process is still unknown.

\section{ULTRASTRUCTURAL STUDIES}

Ultrastructural studies in T. cruzi have been conducted in order to define the localization and distribution of peptidases in the parasite since the involvement of peptidases in the process of T. cruzi-host cell interaction was described [105, 106]. Further studies not only confirmed those findings but also showed the role of peptidases in the intracellular survival, replication and differentiation of the parasite and in disease pathology $[23,32,58,90,107,108]$. Although immunofluorescence techniques have been used to date to locate the peptidases in $T$. cruzi, immunocytochemistry, with the aid of electrondense markers such as colloidal gold particles, is the best choice for enzyme localization due to the reduced dimensions of the parasite. With transmission electron microscopy, it is possible to identify not only the location of the enzymes in the cell but also their sites of accumulation and the compartments in the endocytic/exocytic pathways they flow through (Fig. 1).

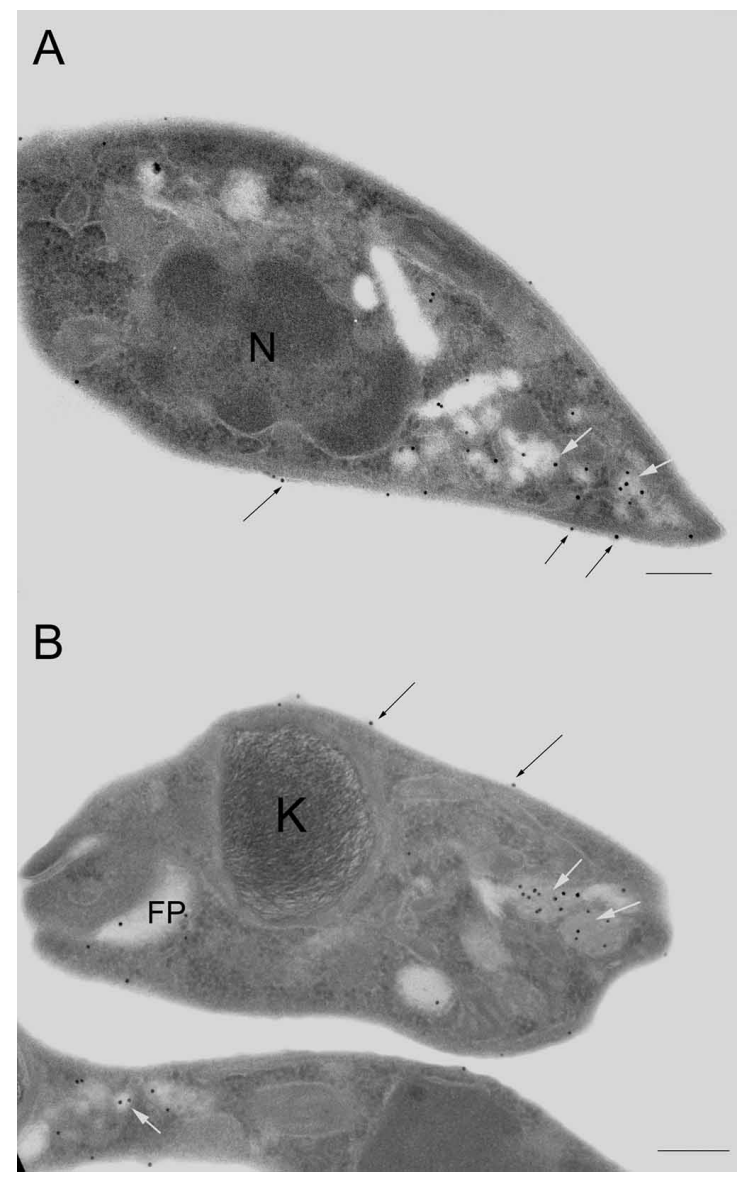

Fig. (1). Immunocytochemical detection of cruzipain in T. cruzi amastigotes (A) and trypomastigotes (B). Parasites were fixed under conditions to preserve antigens and embedded in a hydrophilic resin to allow immunocytochemical detection in ultra-thin sections. Sections were incubated with an anti-cruzipain polyclonal antibody [32] and with goat anti-rabbit IgG coupled to colloidal gold (diameter $8-10 \mathrm{~nm}$ ). Particles were observed on the surface of both developmental forms (small black arrows), in the flagellar pocket (FP) and in lysosomal-related organelles (white arrows). N, nucleus; $\mathrm{K}$, kinetoplast. Bars $=0.25 \mu \mathrm{m}$. 
The first peptidase located using immunocytochemical techniques in T. cruzi was cruzipain (CZP) [32, 108-110]. Antibodies against CZP were obtained by different groups. Both monospecific polyclonal and monoclonal antibodies against cruzipain-1 or GP57/51 isolated from epimastigotes and its recombinant enzyme named cruzain, as well as a polyclonal antibody against the recombinant cruzipain-2, an isoform that is preferentially expressed by trypomastigotes and amastigotes were produced [111-114].

Immunocytochemical labeling with anti-CZP antibodies revealed the presence of $\mathrm{CZP}$ in four main sites: in the cytoplasmic compartments, in the flagellar pocket, on the cell body and on the flagellar membranes (Fig. 1). The evidence that the cysteine peptidase activity takes place in cytoplasmic compartments came from the studies of Bontempi [115]. Additional immunocytochemical studies showed the enzyme to be located inside enclosed membrane compartments located at the posterior region of the parasite. The positive compartments observed in all developmental forms, are closely related and defined as lysosomal-related organelles (LROs) since they share some functional characteristics with the lysosomes of mammalian cells [34]. In epimastigotes, $\mathrm{CZP}$ positive compartments are named reservosomes and have two functions: degradation and storage of macromolecules $[116,117]$. In trypomastigotes, CZP can be observed in round organelles located between the nucleus and the kinetoplast in a region very close to the flagellar pocket. In amastigotes, CZP is observed in round and/or tubular organelles $[34,108]$.

The flagellar pocket of all developmental forms of the parasite is frequently labeled suggesting that the enzyme is secreted through this region. Gold particles can be observed associated to the membrane or free inside the pocket. The amount of gold particles within the pocket is variable among the individuals in a sample indicating that the process of CZP release could be modulated by the parasite or related to a particular stage of development since $T$. cruzi samples are naturally not synchronized. The same pattern of labeling is observed in the three developmental forms.

Cruzipain is also observed on the membrane that encloses the cell body and the flagellum but the intensity of labeling is quite different among the developmental forms of T. cruzi and varies with the antibody used. Very few or no gold particles indicative of the presence of CZP were seen in association with the surface of most trypomastigote forms $[32,34,108]$ labeled with anti-cruzipain-1 antibodies. It is not clear how CZP leaves the Golgi and reaches the reservosomes and the flagellar pocket. However, treatment with drugs shed some light on the different ways CZP could be distributed through the parasite as well as the mechanisms that control the intracellular traffic. The use of cysteine peptidase inhibitors (CPI) resulted in significant alterations in the localization of CZP in epimastigotes, and it seems to be related to the inhibition of the autocatalytic processing of CZP. When CPIs are used there is an accumulation of the enzyme within the Golgi complex that becomes dilated, a decrease in the amount of CZP within reservosomes and a marked increase in the number of vesicles trafficking from the Golgi to the flagellar pocket where a large amount of the inactive enzyme is secreted [118-120].
Local anesthetics, such as dibucaine, also subverted the regular traffic of $\mathrm{CZP}$ towards different compartments in epimastigotes. Local anesthetics were found to inhibit the activation of a cytoplasmic, calcium-independent, phospholipase A2 (iPLA2), resulting in a significant inhibition of intracellular, membrane-bound compartment fusions along the endocytic and secretory [121-123]. Dibucaine did not affect the total proteolytic activity in epimastigote forms but induced a delay in the endocytic and exocytic processes. The immunocytochemical detection of cruzipain in Db-treated epimastigotes showed that the amount of CZP in reservosomes displayed a $70 \%$ reduction as compared with control cells. In some cells, an accumulation of CZP in the Golgi complex was also observed [124]. More recently, a lysosomal serine carboxypeptidase activity was also described in $T$. cruzi [51]. This enzyme colocates with CZP in the LROs of trypomastigotes and amastigotes [34].

\section{PEPTIDASES AS DRUG TARGET}

Although a wide list of known classes of compounds have been assayed in vitro and in vivo against $T$. cruzi, e.g. allopurinol [125], only two drugs have been approved worldwide for the treatment of Chagas disease, nifurtimox and benznidazole. These drugs were discovered over three decades ago [125-127]. Both of them have significant limitations due to their efficiency solely during the acute phase of the disease. Also, they have significant toxicity and cause unpleasant side effects [128]. The lack of efficient treatment has stimulated efforts to identify new, less toxic and more effective chemotherapy against this parasite [129].

Much of this effort is concentrated on the search for new therapeutic targets for the treatment of Chagas disease. This research uses new technologies such as combinatorial chemistry and structure-based drug design [130].

Peptidases have been widely studied and their inhibitors employed for the treatment of many human diseases, including hypertension and HIV infection and other diseases like diabetes, cancer, thrombosis, osteoporosis, as well as parasitic disease [131].

Peptidase inhibitors have also been considered attractive anti-T.cruzi targets. The selective inhibitors of these peptidases have shown the ability to block the proliferation of the parasite and to arrest metacyclogenesis in vitro [132].

In $T$. cruzi, the most widely studied peptidase is cruzipain, which is considered an important target of rational drug

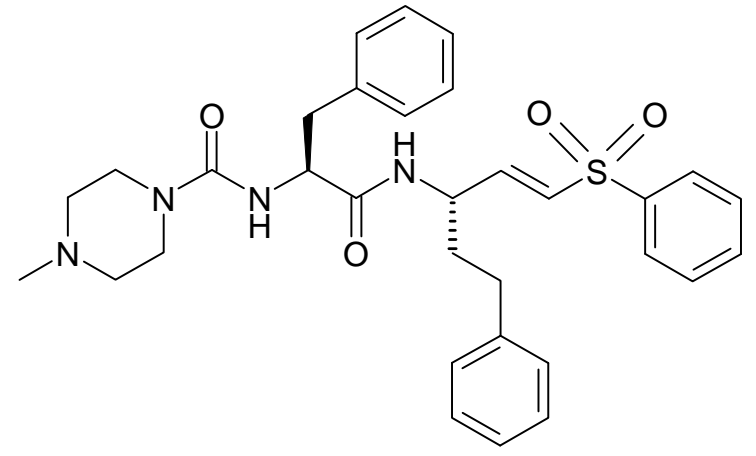

Fig. (2). Chemical structure of the cysteine peptidase inhibitor K777. 
Table 2. Patented Cysteine Inhibitors for Chemotherapy of Chagas Disease. Based on Duschak \& Couto [134]

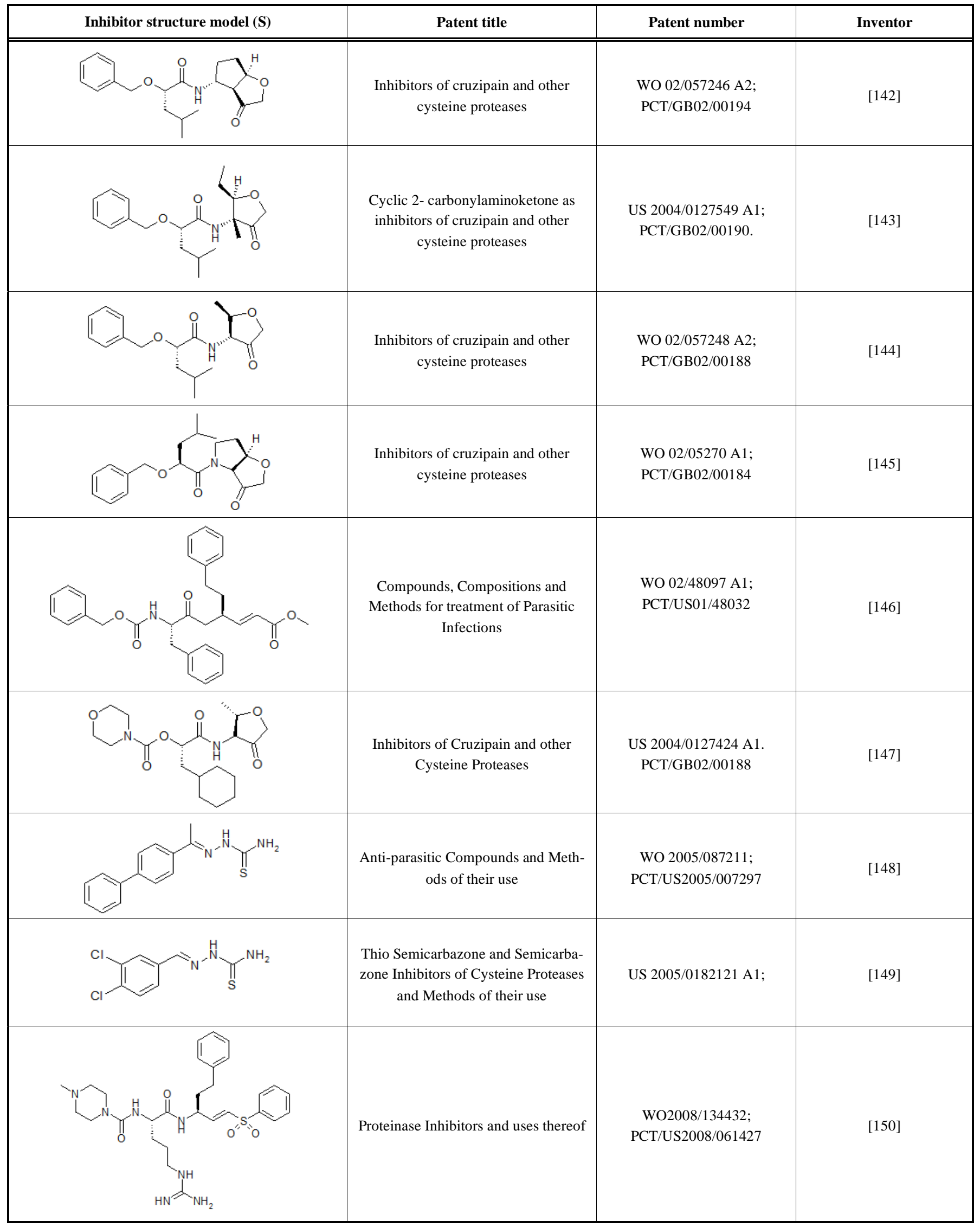


design. This cysteine peptidase is expressed throughout the life cycle and has a wide role in parasite nutrition. Cruzipain has been reported to be involved in the penetration of the parasite into the host cell, as well as in the digestion of immunoglobulins as a defense mechanism. Therefore, the scientific community has demonstrated great interest in the development of new selective cruzipain inhibitors [133]. This target has been explored extensively in recent years as a new and potential chemotherapeutic strategy. It is worth mentioning that 51 patents were issued from 2000 to early 2006 for different drugs targets, both natural and synthetic trypanocidal compounds (ergosterol biosynthesis, synthesis of polyisoprenoids, redox metabolism, DNA nucleotide synthesis, acidocalcisome nucleus, sialic acid transference, cruzipain inhibitors, among others). More than $50 \%$ of these patents encompass cruzipain inhibitors (CPI). The CPI chemical structures are diverse and could be divided in synthetic peptidyl and non-peptidyl (thiosemicarbazone) inhibitors. The synthetic peptidyl compounds can be separated into two groups: irreversible (peptidyl diazomethane inhibitors, peptidyl ketone based inhibitors, peptidyl sulphone inhibitors) and reversible (bis-arylacylhydrazides, aryl ureas, ketone based inhibitors, azepanone based inhibitors, nitrile based inhibitors) inhibitors [127,134].

Many of these inhibitors have presented a lack of selectivity, and therefore show toxicity or have shown to be potent CPIs but with little effectiveness against $T$. cruzi in cell culture $[114,135,136]$. Accordingly, a new generation of CPIs has been synthesized with chemical modifications to improve specificity and in vivo stability, minimizing toxicity. In this regard, K777 (N-methyl-piperazine-urea-FhF-vinylsulfone-phenyl) may be highlighted (Fig. 2) as a vinyl sulfone that is in late-stage preclinical development, showing good efficacy against different organisms, including $T$. cruzi $[127,136,137]$. In addition, novel CPI classes were studied, presenting the same activity than nifurtimox without its toxicity, for example, quinoxaline-N-acylhydrazone derivatives [138]. Moreover, other peptidases of T. cruzi have been identified as promising targets for the design of potential trypanocidal drugs, such as $T$. cruzi prolyl oligopeptidase (Tc80) a serine protease. The synthetic prolylprolyl isoxazoles and prolylprolyl isoxazolines, potent inhibitors of human and trypanosomal prolyl oligopeptidase reduce the invasive capacity of $T$. cruzi in vitro with ED50 in the lower $\mu \mathrm{M}$ range $[139,140]$. Although some metallopeptidases and proteasome (threonine peptidases) have been correlated with the $T$. cruzi virulence factor, no studies concerning their inhibitors are available for T. cruzi [127].

In a recent review of patented drugs for chemotherapy of Chagas disease, Duschak \& Couto [141] described several patented cysteine peptidases inhibitors that could be potentially used for Chagas disease. Table 2 summarizes some of them and new cysteine-inhibitors were added to the list.

\section{PERPECTIVES}

Chagas disease affects millions of individuals in the Americas. Since the current drugs present serious side effects and do not cure the chronic infection [128], it is critically important to understand the process of cellular infection at the molecular and structural levels to design novel inhibitors to block T. cruzi infection. Peptidases are amazing molecules both because of their diversity in structure and range of biological functions [16]. Studies of peptidases have already revealed exciting new insights into the biology of parasitic protozoa [24]. Future directions in this area must consider analyzing the molecular and cellular basis of $T$. cruzi peptidases that are important for mammalian host infection. The candidate genes coding for $T$. cruzi peptidases and peptidase inhibitors involved in this process need to be intensely studied [92]. The progress made in this area may also facilitate the development of novel cell-based therapies to improve the health conditions of current Chagas disease patients [38].

\section{ACKNOWLEDGEMENTS}

We thank David Graham Straker for helpful comments on previous versions of the manuscript. Research done in the authors' laboratories, included in this review, was supported by grants and fellowships from FAPERJ, CNPq and CAPES. Address for reprint requests and other correspondence: A. B. Vermelho, Instituto de Microbiologia Prof. Paulo de Góes, UFRJ, Centro de Ciências da Saude, bloco I, Cidade Universitaria, 21949-900, Rio de Janeiro, RJ, Brasil (E-mail: abvermelho@micro.ufrj.br).

\section{REFERENCES}

[1] Villalta F, Scharfstein J, Ashton AW, et al. Perspectives on the $T$. cruzi-host cell receptor interactions. Parasitol Res 2009; 104: 125160 .

[2] O’Connell D. Neglected diseases. Nature 2007; 449: 157-82.

[3] Hotez PJ, Molyneux DH, Fenwick A, et al. Control of Neglected Tropical Diseases. New Engl J Med 2007; 357: 1018-27.

[4] Gutteridge WE. Designer drugs: pipe-dreams or realities? Parasitology 1997; 114 (Suppl): S145-51.

[5] Beyrer C, Villar JC, Suwanvanichkij V, Singh S, Baral SD, Mills EJ. Neglected diseases, civil conflicts, and right to health. Lancet 2007; 370: 619-27.

[6] Barrett MP, Burchmore RJS, Stich A, et al. The trypanosomiases. Lancet 2003; 362: 1469-80.

[7] WHO Expert Committee. Control of Chagas disease. World Health Organ Tech Rep Ser 2002; 905: 1-109.

[8] Tanowitz HB, Kirchhoff LV, Simon D, Morris SA, Weiss LM, Murray Witfner M. Chagas' Disease. Clin Microbiol Rev 1992; 5: 400-19.

[9] Cazzulo JJ. Proteinases of T. cruzi: patential targets for the chemoterapy of Chagas disease. Curr Trop Med Chem 2002; 2: 126171.

[10] Urbina JA. Chemotherapy of Chagas disease. Curr Pharm Des 2002; 8: 287-95.

[11] Viotti R, Vigliano C, Lococo B, et al. A. Drug Profile: Side effects of benznidazole as treatment in chronic Chagas disease: fears and realities. Exp Rev Anti-infective Ther 2009; 7: 157-63.

[12] Burleigh BA, Andrews NW. A $120 \mathrm{kDa}$ alkaline peptidase from T. cruzi is involved in the generation of a novel $\mathrm{Ca}^{2+}$-signalling factor for mammalian cells. J Biol Chem 1995; 270: 5172-180.

[13] Andrade LO, Andrews NW. The Trypanosoma cruzi-host-cell interplay: location, invasion, retention. Nat Rev Microbiol 2005; 3: 819-23.

[14] Klemba M, Goldberg DE. Biological roles of proteases in parasitic protozoa. Annu Rev Biochem 2002; 71: 275-305.

[15] McKerrow JH, Rosenthal PJ, Swenerton R, Doyle P. Development of protease inhibitors for protozoan infections. Curr Opin Infect Dis 2008; 21: 668-72.

[16] Rawlings ND, Morton FR, Kok CY, Kong J, Barrett AJ. MEROPS: the peptidase database. Nucleic Acids Res 2008; 36: D320-25.

[17] Hartley BS. Proteolytic enzymes. Annu Rev Biochem 1960; 29: 45-72.

[18] Rawlings ND, Barrett AJ. Evolutionary families of peptidases. Biochem J 1993; 290: 205-18. 
[19] Ivens AC, Peacock CS, Worthey EA, et al. (Tables S17 and S18) The genome of the kinetoplastid parasite, Leishmania major. Science 2005; 15: 309(5733): 436-42.

[20] El-Sayed NM, Myler PJ, Bartholomeu DC, et al. The genome sequence of Trypanosoma cruzi, etiologic agent of Chagas disease. Science 2005; 309: 409-15.

[21] Kosec G, Alvarez V, Cazzulo JJ. Cysteine proteinases of Trypanosoma cruzi: from digestive enzymes to programmed cell death mediators. Biocell 2006; 30: 479-90.

[22] Pinho RT, Beltramini LM, Alves CR, De-Simone SG. Trypanosoma cruzi: isolation and characterization of aspartyl proteases. Exp Parasitol 2009; 122: 128-33.

[23] Meirelles MN, Juliano L, Carmona E, et al. Inhibitors of the major cysteinyl proteinase (GP57/51) impair host cell invasion and arrest the intracellular development of Trypanosoma cruzi in vitro. $\mathrm{Mol}$ Biochem Parasitol 1992; 52: 175-84.

[24] Vermelho AB, Giovanni-de-Simone S, d'Avila-Levy CM, et al. Trypanosomatidae peptidases: a target for drugs development. Curr Enz Inhib 2007; 3: 19-48.

[25] Vermelho AB, Melo ACN, Branquinha MH, et al. Enzimas proteolíticas: Aplicações Biotecnológicas. In: Bon EPS, Corvo Vermelho AB, Paiva CLA, Ferrara MA, Coelho RR, Alencastro RB, Ed. Enzimas em Biotecnologia: Produção, Aplicações e Mercado 2008; pp. 273-287.

[26] Atkinson HJ, Babbitt PC, Sajid M. The global cysteine peptidase landscape in parasites. Trends Parasitol 2010; 25: 573-81.

[27] Rangel HA, Araújo PMF, Repka D, Costa MG. Trypanosoma cruzi: isolation and characterization of a proteinase. Exp Parasitol 1981; 52: 199-209.

[28] Ashall F. Characterization of an alkaline peptidase of Trypanosoma cruzi and other trypanosomatids. Mol Biochem Parasitol 1990; 38: 77-80.

[29] Garcia MP, Nóbrega OT, Teixeira ARL, Sousa MV, Santana JM. Characterization of a Trypanosoma cruzi acidic $30 \mathrm{kDa}$ cysteine protease. Mol Biochem Parasitol 1998; 91: 263-72.

[30] Giese V, Dallagiovanna B, Marchini FK, Pavoni DP, Krieger MA, Goldenberg S. Trypanosoma cruzi: a stage-specific calpain-like protein is induced after various kinds of stress. Mem Inst Oswaldo Cruz 2008; 3: 598-601.

[31] Sangenito LS, Ennes-Vidal V, Marinho FA, et al. Arrested growth of Trypanosoma cruzi by the calpain inhibitor MDL28170 and detection of calpain homologues in epimastigote forms. Parasitology 2009; 136: 433-41.

[32] Murta ACM, Persechini PM, de Souto Padrón T, de Souza W, Guimaraes JÁ, Scharfstein J. Structural and functional identification GP57/51 antigen of Trypanosoma cruzi as a cysteine proteinase. Mol Biocem Parasitol 1990; 43: 27-38.

[33] Cazzulo JJ, Labriola C, Parussini F, Duschak VG, Martinez J, Franke de Cazzulo BM. Cysteine proteinase in Trypanosoma cruzi and other trypanosomatid protozoa. Acta Chim Slov 1995; 42: 40918 .

[34] Sant'Anna C, Parussini F, Lourenço D, de Souza W, Cazzulo JJ, Cunha-e-Silva NL. All Trypanosoma cruzi developmental forms present lysosome-related organelles. Histochem Cell Biol 2008; 130: 1187-98.

[35] Caffrey CR, Scory S, Steverding D. Cysteine Proteinases of Trypanosome Parasites: Novel Targets for Chemotherapy. Curr Drug Targets 2000; 1: 155-62.

[36] Duschak VG, Barboza M, García GA, Lammel EM, Couto AS, Isola EL. Novel cysteine proteinase in Trypanosoma cruzi metacyclogenesis. Parasitology 2006; 132: 345-55.

[37] Lima AP, Almeida PC, Tersariol IL, et al. Heparan sulfate modulates kinin release by Trypanosoma cruzi through the activity of cruzipain. J Bio Chem 2002; 277: 5875-81.

[38] Villalta F, Madison NM, Kleshchenko Y, Nde PN, Lima MF. Molecular analysis of early host cell infection by Trypanosoma cruzi. Front Biosci 2008; 13: 3714-34.

[39] Nóbrega OT, Santos Silva M, Teixeira ARL, Santana JM. Molecular cloning of tccb, a gene encoding a Trypanosoma cruzi cathepsin B-like protease. Mol Biochem Parasitol 1998; 97: 235-40.

[40] Yong V, Schmitz V, Vannier-Santo MA, Lima AP, Lamanach G, Juliano L. Altered expression of cruzipain and a cathepsin B-like target in a Trypanosoma cruzi cell line displaying resistance to synthetic inhibitors of cysteine-proteinases. Mol Biochem Parasitol 2000; 109: 47-59.
[41] Fernandes LC, Bastos MDI, Lauria-Pires L, et al. Specific human antibodies do not inhibit Trypanosoma cruzi oligopeptidase B and cathepsin B, and immunoglobulin G enhances the activity of trypomastigote-secreted oligopeptidase B. Microbes Infect 2005; 7: 375-84.

[42] Mottram JC, Helms MJ, Coombs GH, Sajid M. Clan CD. Cysteine peptidases of parasitic protozoa. Trends Parasitol 2003; 19: 182-7.

[43] Jimenez V, Paredes R, Sosa MA, Galanti N. Natural Programmed Cell Death in T. cruzi Epimastigotes Maintained in Axenic Cultures. J Cell Biochem 2008; 105: 688-98.

[44] Ono Y, Sorimachi H, Suzuki K. Structure and Physiology of Calpain, an enigmatic protease. Biochem Biophys Res Commun 1998; 245: 289-94.

[45] McKerrow JH, Rosenthal PJ, Swenerton R, Doyle P. Development of protease inhibitors for protozoan infections. Curr Opin Infect Dis 2008; 21: 668-72.

[46] Burleigh BA, Caler EVC, Webster P, Andrews NW. A cytosolic serine endopeptidase from Trypanosoma cruzi is required for the generation of Ca signaling in mammalian cells. J Cell Biol 1997; 136: 609-20.

[47] Caler EV, Vaena de Avalos S, Haynes PA, Andrews NW, Burleigh B. A. Oligopeptidase B-dependent signaling mediates host cell invasion by Trypanosoma cruzi. EMBO J 1998; 17: 4975-86.

[48] Grellier P, Vendeville S, Joyeau R, et al. Trypanosoma cruzi prolyl oligopeptidase Tc80 is involved in nonphagocytic mammalian cell invasion by trypomastigotes. J Biol Chem 2001; 276: 47078-86.

[49] Bastos IM, Grellier P, Martins NF, et al. Molecular, functional and structural properties of the prolyl oligopeptidase of Trypanosoma cruzi (POP Tc80), which is required for parasite entry into mammalian cells. Biochem J. 2005; 15: 388(Pt 1): 29-38.

[50] McKerrow JH, Caffrey C, Kelly B, Loke P, Sajid M. Proteases in parasitic diseases. Annu Rev Pathol 2006; 1: 497-536.

[51] Parussini F, García M, Mucci J, et al. Characterization of a lysosomal serine carboxypeptidase from Trypanosoma cruzi. Mol Biochem Parasitol 2003; 131: 11-23.

[52] Branquinha MH, Vermelho AB, Goldenberg S, Bonaldo MC. Ubiquity of cysteine- and metalloproteinase activities in a wide range of trypanosomatids. J Eukaryot Microbiol 1996; 43: 131-5.

[53] Nogueira de Melo AC, d'Avila-Levy CM, Dias FA, et al. Peptidases and gp63-like proteins in Herpetomonas megaseliae: possible involvement in the adhesion to the invertebrate host. Int $\mathrm{J}$ Parasitol 2006; 36: 415-22.

[54] Santos AL, Soares RM, Alviano CS, Kneipp LF. Heterogeneous production of metallo-type peptidases in parasites belonging to the family Trypanosomatidae. Eur J Protistol 2008; 44: 103-13.

[55] Grandgenett PM, Coughlin BC, Kirchhoff LV, Donelson JE. Differential expression of GP63 genes in Trypanosoma cruzi. Mol Biochem Parasitol 2000; 110: 409-15.

[56] Bonaldo MC, d'Escoffier LN, Salles JM, Goldenberg S. Characterization and expression of proteases during Trypanosoma cruzi metacyclogenesis. Exp Parasitol 1991; 73: 44-51.

[57] Lowndes CM, Bonaldo MC, Thomaz N, Goldenberg S. Heterogeneity of metalloprotease expression in Trypanosoma cruzi. Parasitology 1996; 112: 393-99.

[58] Cuevas IC, Cazzulo JJ, Sanchez DO. gp63 homologues in Trypanosoma cruzi: surface antigens with metalloprotease activity and a possible role in the host cell infection. Infect Immun 2003; 71: 5739-49.

[59] Cockle JA, Gopichandran N, Walker JJ, Levene MI, Orsi NM. Matrix Metalloproteinases and Their Tissue Inhibitors in Preterm Perinatal Complications. Reprod Sci 2007; 14: 629-45.

[60] Nogueira de Melo AC, Meirelles MNL, Porrozzi R, Costa JD, Branquinha $\mathrm{MH}$, Vermelho AB. Reduced activity of matrix metalloproteinase-9 in Trypanosoma cruzi infected mouse embryo hepatocyte cell. Hepatol Res 2004; 28, 49-56.

[61] Burleigh BA, Woolsey AM. Cell signaling and Trypanosoma cruzi invasion. Cell Microbiol 2002; 4: 701-11.

[62] Gutierrez FR, Mariano FS, Lalu MM, et al. Increased activities of cardiac matrix metalloproteinases matrix metalloproteinase (MMP)- 2 and MMP-9 are associated with mortality during the acute phase of experimental Trypanosoma cruzi infection. J Infect Dis 2008; 197: 1468-76.

[63] Nogueira de Melo, Souza EP, Ramalho CEG, et al. Detection of matrix metallopeptidase-9-like proteins in Trypanosoma cruzi. Exp Parasitol 2010; 125: 256-63. 
[64] Niemirowicz G, Parusini F, Aguero F, Cazulo JJ. Two metallocarboxipeptidases from the protozoan Trypanosoma cruzi belong to the M32 family, found so far only in prokaryotes. Biochem J 2007; 401: 399-410.

[65] Niemirowicz G, Fernández D, Solá M, Cazzulo JJ, Avilés FX, Gomis-Ruth FX. The molecular analysis of Trypanosoma cruzi metallocarboxipeptidase 1 provides insight into fold and substrate specificity. Mol Microbiol 2008; 70: 853-66.

[66] Ciechanover A. The ubiquitin-proteasome proteolytic pathway. Cell 1994; 79:13-21

[67] Goldberg AL, Akopian TN, Kisselev AF, Lee DH, Rohrwold M. New insights into the mechanisms and importance of the proteasome in intracellular protein degradation. Biol Chem 1997; 378: $131-40$.

[68] Zwickl P, Baumeister W. The Proteasome-ubiquitin Protein Degradation Pathway. Curr Top Microbiol Immunol 2002; 268: 1- 209.

[69] Pahl HL, Baeuerle PA. Control of gene expression by proteolysis. Curr Opin Cel Biol 1996; 8: 340-7.

[70] Groettrup M, Souza A, Kuckelkorn U, Kloetzelt PM. Peptide antigen production by the proteasome: complexity provides efficiency. Immunol Today 1996; 17: 429-35.

[71] Pagano M. Cell cycle regulation by the ubiquitin pathway. FASEB J 1997; 11: 1067-75.

[72] Bonifacino JS, Weissman AM. Ubiquitin and the control of protein fate in the secretory and endocytic pathways. Annu Rev Cell Biol $1998 ; 14: 19-57$

[73] Schubert U, Antón LC, Gibbs J, Norbury CC, Yewdell JW, Bennink JR. Rapid degradation of a large fraction of newly synthesized proteins by proteasomes. Nature 2000; 404: 770-74.

[74] Kisselev AF, Goldberg AL. Proteasome inhibitors: from research tools to drug candidates. Chem Biol 2001; 8: 739-58.

[75] Coux O, Tanaka K, Goldberg AL. Structure and functions of the $20 \mathrm{~S}$ and 26S proteasomes. Ann Rev Biochem 1996; 65: 801-47.

[76] Groll M, Huber R. Inhibitors of the eukaryotic 20S proteasome core particle: a structural approach. Biochim Biophys Acta 2004; 1695: 33-44

[77] De Diego JL, Katz JM, Marshall P, et al. The ubiquitin-proteasome pathway plays an essential role in proteolysis during Trypanosoma cruzi remodeling. Biochemistry 2001; 40: 1053-62.

[78] Rubin DM, Glickman MH, Larsen CN, Dhruvakumar S, Finley D. Active site mutants in the six regulatory particle ATPases reveal multiple roles for ATP in the proteasome. Embo J 1998; 17: 490919.

[79] Hua SB, To WY, Nguyen TT, Wong ML, Wang CC. Purification and characterization of proteasomes from Trypanosoma brucei. Mol Biochem Parasitol 1996; 78: 33-46.

[80] Zou CB, Nakajima-Shimada J, Nara T, Aoki T. Cloning and functional expression of Rpn1, a regulatory-particle non-ATPase subunit 1, of proteasome from Trypanosoma cruzi. Mol Biochem Parasitol 2000; 110: 323-31.

[81] Bartholomeu DC, Batista JAN, Vainstein MH, Lima BD, Sá MC. Molecular cloning and characterization of a gene encoding the 29kDa proteasome subunit from Trypanosoma cruzi. Mol Genet Genomics 2001; 265: 986-92.

[82] Nkemngu NJ, Rosenkranz V, Wink M, Steverding D. Antitrypanosomal activities of proteasome inhibitors. Antimicrob Agents Chemother 2002; 6: 2038-40.

[83] Tomlinson S, Vandekerchov F, Frevert U, Nussenzweig V.The induction of Trypanosoma cruzi trypomastigote to amastigote transformation by low pH. Parasitology 1995; 110: 547-55.

[84] Gonzalez J, Pinto-Ramalho JF, Frevert U, et al. Proteasome activity is required for the stage-specific transformation of a protozoan parasite. J Exp Med 1996; 184: 1909-18.

[85] Cardoso J, Soares MJ, Menna-Barreto RFS, et al. Inhibition of proteasome activity blocks Trypanosoma cruzi growth and metacyclogenesis. Parasitol Res 2008; 103: 941-51.

[86] Rock KL, Gramm C, Rothstein L, et al. Inhibitors of the proteasome block the degradation of most cell proteins and the generation of peptides presented on MHC class I molecules. Cell 1994; 78: $761-71$.

[87] Pinho RT, Beltramini LM, Alves CR, De-Simone SG. Trypanosoma cruzi: isolation and characterization of aspartyl protease. Exp Parasitol 2009; 122: 128-33.

[88] Sajid M, McKerrow JH. Cysteine proteases of parasitic organisms. Mol Biochem Parasitol 2002; 120:1-21.
[89] Costales J, Rowland EC. A role for protease activity and host-cell permeability during the process of Trypanosoma cruzi egress from infected cells. J Parasitol 2007; 93: 1350-9.

[90] Scharfstein J, Lima AP. Roles of naturally occurring protease inhibitors in the modulation of host cell signaling and cellular invasion by Trypanosoma cruzi. Subcell Biochem 2008; 47: 140-54

[91] Yoshida N, Cortez M . Trypanosoma cruzi: parasite and host cell signaling during the invasion process. Subcell Biochem 2008; 47: 82-91.

[92] Burleigh BA, Andrews NW. The mechanisms of Trypanosoma cruzi invasion of mammalian cells. Annu Rev Microbiol 1995; 49: 175-200.

[93] Waghabi MC, Keramidas M, Calvet CM, et al. SB-431542, a transforming growth factor beta inhibitor, impairs Trypanosoma cruzi infection in cardiomyocytes and parasite cycle completion. Antimicrob Agents Chemother 2007; 51: 2905-10.

[94] Woolsey AM, Sunwoo L, Petersen CA, Brachmann SM, Cantley LC, Burleigh BA. Novel PI 3-kinase-dependent mechanisms of trypanosome invasion and vacuole maturation. J Cell Sci 2003; 116: 3611-22.

[95] Caler EV, Morty RE, Burleigh BA, Andrews NW. Dual role of signaling pathways leading to $\mathrm{Ca}^{2+}$ and cyclic AMP elevation in host cell invasion by Trypanosoma cruzi. Infect Immun 2000; 68 : 6602- 10

[96] Tardieux I, Nathanson MH, Andrews NW. Role in host cell invasion of Trypanosoma cruzi-induced cytosolic free $\mathrm{Ca}^{2+}$ transients. J Exp Med 1994; 179: 1017-22.

[97] Rodríguez A, Rioult MG, Ora A, Andrews NW. A trypanosomesoluble factor induces IP3 formation, intracellular $\mathrm{Ca}^{2+}$ mobilization and microfilament rearrangement in host cells. J Cell Biol 1995; 129: 1263-73.

[98] Yoshida N. Molecular basis of mammalian cell invasion by Trypanosoma cruzi. An Acad Bras Cienc 2006; 78: 87-111.

[99] Caler EV, Chakrabarti S, Fowler KT, Rao S, Andrews NW. The Exocytosis-regulatory protein synaptotagmin VII mediates cell invasion by Trypanosoma cruzi. J Exp Med 2001; 193: 1097-104

[100] Scharfstein J, Schmitz V, Morandi V, et al. Host cell invasion by Trypanosoma cruzi is potentiated by activation of bradykinin $\mathrm{B}(2)$ receptors. J Exp Med 2000; 192:1289-300

[101] Todorov AG, Andrade D, Pesquero JB, et al. Trypanosoma cruzi induces edematogenic responses in mice and invades cardiomyocytes and endothelial cells in vitro by activating distinct kinin receptor (B1/B2) subtypes. Faseb J 2003; 17: 73-5.

[102] Santos CC, Sant'anna C, Terres A, Cunha-e-Silva NL, Scharfstein J, de A Lima AP. Chagasin, the endogenous cysteine-protease inhibitor of Trypanosoma cruzi, modulates parasite differentiation and invasion of mammalian cells. J Cell Sci 2005; 118: 901-15.

[103] Salmon D, do Aido-Machado R, Diehl A, et al. Solution structure and backbone dynamics of the Trypanosoma cruzi cysteine protease inhibitor chagasin. J Mol Biol 2006; 357: 1511-21.

[104] Mottram JC, Brooks DR, Coombs GH. Roles of cysteine proteinases of trypanosomes and Leishmania in host-parasite interactions. Curr Opin Microbiol 1998; 1: 455-60.

[105] Piras MM, Henriquez D, Piras R. The effect of proteolytic enzymes and protease inhibitors on the interaction Trypanosoma cruzifibroblasts. Mol Biochem Parasitol 1985; 14: 151-63.

[106] de Araujo-Jorge TC, Sampaio EP, de Souza W. Trypanosoma cruzi inhibition of host cell uptake of infective bloodstream forms by alpha 2 macroglobulin. Z Parasitenkd. 1986; 72: 323-9.

[107] Eakin AE, Mills AA, Harth G, McKerrow JH, Craik CS. The sequence, organization, and expression of the major cysteine protease (cruzain) from Trypanosoma cruzi. J Biol Chem 1992; 267: 741120.

[108] Souto-Padrón T, Campetella EO, Cazzulo JJ, de Souza W. Cysteine proteinase of Trypanosoma cruzi localization and involvement in parasite-host cell interaction. J Cell Sci 1990; 96: 485-90.

[109] Cazzulo JJ, Stoka V, Turk V. Cruzipain the major cysteine proteinase from the protozoan parasite Trypanosoma cruzi. Biol Chem 1997; 378: 1-10.

[110] Souto-Padrón T, Reyes MB, Leguizamon S, Campetella OE Frasch ACC, de Souza W. Trypanosoma cruzi proteins which are antigenic during human infection are located in defined regions on the parasite. Eur J Cell Biol 1989; 50: 272-8.

[111] Campetella O, Martinez J, Cazzulo JJ. A major cysteine proteinase is developmentally regulated in Trypanosoma cruzi. FEMS Microbiol Lett 1990; 67: 145-50. 
[112] Lima AP, dos Reis FC, Serveau C, et al. Cysteine protease isoforms from Trypanosoma cruzi, cruzipain 2 and cruzain, present different substrate preference and susceptibility to inhibitors. Mol Biochem Parasitol 2001; 114: 41-52.

[113] Scharfstein J, Schechter M, Senna M, Peralta JM, Mendonça- Previato L, Miles MA. Trypanosoma cruzi: characterization and isolation of a 57/51,000 m.w. surface glycoprotein (GP57/51) expressed by epimastigotes and bloodstream trypomastigotes. J Immunol 1986; 137: 1336-41.

[114] McKerrow JH. Development of cysteine protease inhibitors as chemotherapy for parasitic diseases: insights on safety, target validation, and mechanism of action. Int J Parasitol 1999; 29: 833- 7.

[115] Bontempi E, Martinez J, Cazzulo JJ. Subcellular localization of a cysteine proteinase from Trypanosoma cruzi. Mol Biochem Parasitol 1989; 33: 43-8.

[116] Soares MJ, De Souza W. Cytoplasmic organelles of trypanosomatids: a cytochemical and stereological study. J Submicrosc Cytol Pathol 1988; 20: 349-61.

[117] Soares MJ, Souto-Padrón T, De Souza W. Identification of a large pre-lysosomal compartment in the pathogenic protozoan Trypanosoma cruzi. J Cell Sci 1992; 102: 157-67.

[118] Engel JC, Doyle PS, Palmer J, Hsieh I, Bainton DF, McKerrow JH. Cysteine protease inhibitors alter Golgi complex ultrastructure and function in Trypanosoma cruzi. J Cell Sci 1998; 111: 597-606.

[119] Engel JC, Doyle PS, Hsieh I, McKerrow JH. Cysteine protease inhibitors cure an experimental Trypanosoma cruzi infection. J Exp Med 1998; 188: 725-34

[120] Engel JC, Torres C, Hsieh I, Doyle PS, McKerrow JH. Upregulation of the secretory pathway in cysteine protease inhibitor-resistant Trypanosoma cruzi. J Cell Sci 2000; 113: 1345-54.

[121] Lennartz MR, Yuen AF, Masi SM, Russell DG, Buttle KF, Smith JJ. Phospholipase A2 inhibition results in sequestration of plasma membrane into electronlucent vesicles during IgG-mediated phagocytosis. J Cell Sci 1997; 110: 2041-52.

[122] De Figueiredo P, Drecktrah D, Katzenellenbogen JA, Strang M, Brown WJ. Evidence that phospholipase A2 activity is required for Golgi complex and trans-Golgi network membrane tubulation. Proc Natl Acad Sci USA 1998; 95: 8642-7.

[123] De Figueiredo P, Drecktrah D, Polizotto RS, Cole NB, Lippincott-Schwartz J, Brown WJ. Phospholipase A2 antagonists inhibit constitutive retrograde membrane traffic to the endoplasmic reticulum. Traffic 2000; 1: 504-11.

[124] Souto-Padrón T, Lima AP, Ribeiro RO. Effects of dibucaine on the endocytic/exocytic pathways in Trypanosoma cruzi. Parasitol Res 2006; 99: 317-20.

[125] Enders JE, Fernández AR, Fretes R, et al. Allopurinol is effective to modify the evolution of Trypanosoma cruzi infection in mice. Parasitol Res 2007; 101: 1459-62.

[126] Docampo R, Urbina JA. Specific chemotherapy of Chagas disease: controversies and advances. Trends Parasitol 2003; 19: 495-501.

[127] Castro SL, Soeiro MZC. Trypanosoma cruzi targets for new chemotherapeutic approaches. Expert Opin Ther Targets 2009; 13: 105-21.

[128] Bahia MT, Caldas IS, Caldas S, et al. Benznidazole therapy during acute phase of Chagas disease reduces parasite load but does not prevent chronic cardiac lesions. Parasitol Res 2008; 103: 413-21.

[129] Ellman JA, Huang L, Lee A. Identification of Potent and Selective Mechanism-Based Inhibitors of the Cysteine Protease Cruzain Using Solid-Phase Parallel Synthesis. J Med Chem 2002; 45: 676-84.

[130] Lombardino JG, Lowe JA. The Role of the Medicinal Chemistry in Drug Discovery - Then and Now. Drug Discov Rev 2004, 3: 85362.
[131] Doyle P, McKerrow JM, Rosenthal PJ, Swenerton R. Development of protease inhibitors for protozoan infections. Curr Opin Infect Dis 2008; 21: 668-72.

[132] Doyle PS, Engel JC, McKerrow JH. Trypanocidal effect of cysteine protease inhibitors in vitro and in vivo in experimental Chagas disease. Medicina 1999; 59 (Suppl II): 171-75.

[133] Baldino CM, Brinen LS, Cheng H, et al. Development of alphaketo- based inhibitors of cruzain, a cysteine protease implicated in Chagas disease. Bioorg Med Chem 2005; 13: 2141-56.

[134] Duschak VG. Couto AS. Insight on targets and patented drugs for chemotherapy of chagas disease. Recent Pat Antiinfect Drug Discov 2007; 2: 19-51.

[135] Gauthier F, Lalmanach G, Mayer R, Scharfstein J, Serveau C. Biotin-labelled peptidyl diazomethane inhibitors derived from the substratelike sequence of cystatin: targeting of the active site of cruzipain, the major cysteine proteinase of Trypanosoma cruzi. Biochem J 1996; 318: 395-99.

[136] Doyle PS, Engel JC, Mckerrow JH, Zhou YM. A Cysteine Protease Inhibitor Cures Chagas' Disease in an Immunodeficient-Mouse Model of Infection. Antimicrob Agents Chemother 2007; 51: 3932 39.

[137] Doyle PS, Engel JC, Hsieh I, Mckerrow JH. Cysteine Protease Inhibitors Cure an Experimental Trypanosoma cruzi Infection. J Exp Med 1998; 188 (4): 725-34

[138] Aguirre G, Aldana I, Barreiro EJ, et al. Synthesis, trypanocidal activity and docking studies of novel quinoxaline-Nacylhydrazones, designed as cruzain inhibitors candidates. Bioorg Med Chem 2009; 17: 641-52.

[139] Andrews NW, Avalos V, Burleigh BA, Caler EV, Haynes PA. Oligopeptidase B-dependent signaling mediates host cell invasion by Trypanosoma cruzi. EMBO J 1998; 17: 4975-86.

[140] Antonov D, Augustyns K, Bal G, et al. Prolylisoxazoles: Potent Inhibitors of Prolyloligopeptidase with Antitrypanosomal Activity. Bioorg Med Chem Lett 2003; 13: 2875-78.

[141] Duschak VG, Couto AS. An insight on targets and patented drugs for chemotherapy of Chagas Disease. Recent Pat Antiinfect Drug Discov 2007; 2: 19-51.

[142] Quibell M, Ramjee MK. Inhibitors of cruzipain and other cysteine proteases. WO 02/057246 A2, PCT/GB02/00194, 2002.

[143] Quibell M. Cyclic 2-carbonylaminoketone as inhibitors of cruzipain and other cysteine proteases. US 2004/0127549 A1, PCT/GB02/00190, 2002

[144] Quibell M. Inhibitors of cruzipain and other cysteine proteases. WO 02/057248 A2, PCT/GB02/00188, 2002.

[145] Quibell M. Inhibitors of cruzipain and other cysteine proteases. WO 02/05270 A1, PCT/GB02/00184, 2002.

[146] Lim-Wilby M, Semple, JE, Araldi GL, et al. Compounds, compositions and methods for treatment of parasitic infections. WO 02/48097 A1, PCT/US01/48032, 2002.

[147] Quibell M, Ramjee MK. Inhibitors of cruzipain and other cysteine proteases. US 2004/0127424 A1, PCT/GB02/00188, 2004.

[148] Chibale K, Geenbaum D, McKeroow JH. Anti-parasitic compounds and methods of their use. WO 2005/087211, PCT/US2005/007297, 2005 .

[149] Cohen FE, Du X, Guo C, et al. Thio semicarbazone and semicarbozone inhibitors of cysteine proteases and methods of their use. US 2005/0182121 A1.

[150] Roush W, Chen YT, Mckerrow JH. Proteinase inhibitors and uses thereof. WO2008/134432, PCT/US2008/061427, 2008.

(C) Vermelho et al.; Licensee Bentham Open.

This is an open access article licensed under the terms of the Creative Commons Attribution Non-Commercial License (http://creativecommons.org/licenses/by-nc/3.0/) which permits unrestricted, non-commercial use, distribution and reproduction in any medium, provided the work is properly cited. 